\title{
Klimatinės paplūdimių turizmo sąlygos Lietuvos jūros krante
}

\section{Simona Dalinkevičiūtè,}

Justas Kažys

Vilniaus universitetas,

M. K. Čiurlionio g. 21,

03101 Vilnius

El.paštas justas.kazys@gf.vu.lt
Dalinkevičiūtė S., Kažys J. Klimatinės paplūdimių turizmo sąlygos Lietuvos jūros krante. Geologija. Geografija. 2018. T. 4(1). ISSN 2351-7549.

Turizmas daugeliui žmonių yra neatsiejama gyvenimo dalis. Kartu su turizmu svarbus ir klimatas, tiksliau, kokios sąlygos būdingos regione, kuriame planuojama praleisti atostogas ar pailsèti. Ypač žmones traukia vandens telkiniai, prie kurių paplūdimiuose galima pasideginti saulëje, pažaisti tinklini ar kitaip praleisti laiką. Šio darbo tikslas - naudojantis turizmo klimato indeksu (TCI), jo modifikuota versija (TCIM), klimato indeksu turizmui (CIT) ir remiantis daugiamečiais 1993-2016 m. duomenimis nustatyti paplūdimių turizmo sąlygas trims Lietuvos pajūrio miestams - Klaipeddai, Palangai ir Nidai - gegužès-rugsèjo mèn. Rezultatai parodè, kad vidutiniškai tiriamuoju laikotarpiu vyrauja nuo gerų iki puikių sąlygų pagal TCI, nuo ribinių iki priimtinų pagal TCIM ir nuo netinkamų iki ribinių, bet priimtinų pagal CIT.

Raktažodžiai: turizmas, klimatas, klimatiniai turizmo indeksai, Lietuvos pajūris

\section{IVADAS}

Turizmui orų sąlygos yra itin svarbios dèl daugelio priežasčių: nuo jų priklauso šalies ekonomika, žmogaus laisvalaikio praleidimas, šalies patrauklumas turistams. Turizmas apskritai yra viena labiausiai plètojamų ir besivystančių ūkio šakų (De Freitas, Matzarakis, 2005). Nuo orų sąlygų priklauso atostogų planavimas, šalies pasirinkimas, o kartais tiesiog laikotarpis, kuriuo planuojama atostogauti. Renkantis kurortą ar tinkamiausią laiką atostogoms reikètų atkreipti démesi i meteorologinių ir mikroklimatinių sąlygų ittaką ligu paūmèjimams, terminiam stresui, kurị gali sukelti aukšta temperatūra ar karščio bangos, ịvertinti regiono klimatoterapijos potencialą. Siekiant maksimaliai išnaudoti mikroklimatinius kurortų ypatumus gydomųų bei sveikatinimo procedūrų efektyvumui padidinti, reikètų žino- ti, kokiems meteorologiniams rodikliams asmuo jautrus ir koks metų laikas yra pats optimaliausias žmogaus sveikatai (Galvonaitè ir kt., 2015).

Klimatas yra itin svarbus, jis veikia turistu komforto lygi ir elgsenos ypatumus (Kūle ir kt., 2013). Klimatines sąlygas turizmui galima nusakyti atskirais meteorologiniais rodikliais (oro temperatūra, kritulių kiekiu, vejjo greičiu ir t. t.) bei jų kaita bėgant laikui (kasdieniai, sezoniniai ar daugiamečiai pokyčiai). Tačiau vertinant klimatinị turizmo potencialą dažniausiai naudojami kompleksiniai įvarius meteorologinius rodiklius integruojantys indeksai. Vienas plačiausiai pasaulyje taikomų indeksų, kuris buvo išbandytas skirtinguose žemynuose ir klimatinèse zonose, yra TCI (angl. Tourism Climate Index), ji 1985 m. pirmą kartą pasiūle Z. Mieczkowskis. Šiuo metu TCI yra populiariausias indeksas vertinant miestų ar kitų vietovių klimatinį-turistini potencialą 
ir klimato tinkamumą bendrajai turizmo veiklai (Tang, 2013).

D. Scottas ir G. McBoyle'as (2001) TCI panaudojo tirdami Šiaurès Amerikos turistinius išteklius. Jie pasirinko 17 miestų taip, kad susidare trys platuminiai skerspjūviai: pirmasis apèmé Meksiką ir JAV pietines valstijas, antrasis - valstijų centrą, o trečiasis - pietinę Kanados dalį. Atlikus tyrimus paaiškèjo, kad visuose Kanados miestuose turizmo pikas būna vasaros mènesiais, pietinèse valstijose - žiemos sezonu. A. Amiranashvilis ir kt. (2008), tirdami TCI reikšmių sezoninę kaitą Tbilisyje (Gruzija), nustatè, kad palankios klimatinès sąlygos turizmui praktiškai išlieka visus metus. TCI buvo panaudotas ir ateities klimato prognozèms. A. Perry (2011) apskaičiavo, kad XXI a. dauguma vasaru gali turèti labai gerų, puikių arba idealių dienų Jungtinèje Karalystejje. Tačiau Viduržemio jūros pakrantès zonos patrauklumas pavasarị ir rudeni dar sustiprètų, palyginti su dabartiniu vertinimu, nes spalio-lapkričio mèn. dèl šilumos ir saulès Viduržemio jūros regionas stipriai kontrastuoja su Šiaurès Europa. Ateityje Baltijos jūros krante turizmo sąlygos turètų gerèti (Moreno, Amelung, 2009; Perch-Nielsen, 2010; Grillakis ir kt., 2016).

Vis dažniau praktikoje naudojamas ne originalus, bet modifikuotas TCI indeksas. G. Hoogendoornas ir J. Fitchettas (2018), tyrinèdami 2016 m. Afrikos žemyno pietinès dalies turistines sąlygas, pritaikè modifikuotą TCI skaičiavimo metodiką. Nustatyta, kad teritorijose, kuriose nebuvo įmanoma gauti saulès spindejjimo trukmès duomenų, jie sèkmingai modifikavo TCI formulę, neịtraukdami saulès spindejjimo trukmès. Ši modifikacija neturèjo didesnio poveikio aukščiausioms TCI reikšmėms, net priešingai - reikšmès išaugo, kadangi saulès spindejjimo trukmès narys labiau skirtas estetiniam nei šiluminiam efektui vertinti. Vengrijos mokslininkai A. Katovcsas ir J. Ungeris (2014) taip pat pritaikè modifikuotą TCI indeksą, užuot panaudoję iprastą oro temperatūros skaičiavimo algoritmą, jie pasitelkè žmogaus šiluminị balansą nusakantị PET (angl. Physiological Equivalent Temperature) indeksą. Tyrimas atliktas šešiuose miestuose: Prahoje, Dere, Šiofoke, Segede, Debrecene ir Salonikuose. Rezultatai parode, kad visuose miestuose buvo gautas bimodalinis paskirstymo tipas. Tai yra maloniausios sąlygos pavasari ir rudeni, o vasa- rą klimato sąlygos yra gana nepalankios dèl itin karštų orų.

CIT (angl. Climate Index for Tourism) indeksas yra naujas, tačiau pasaulyje sparčiai populiarejantis. CIT palengvina sudètinių klimato efektų interpretavimą ir gali būti įvairiai pritaikomas tiek turistams, tiek visam turizmo sektoriui. Turistai ir kelionių operatoriai gali naudoti CIT, norèdami pasirinkti geriausią laiką ir vietą atostogu kelionėms ar planuoti veiklą, atitinkančią numatomam klimatui. Turizmo planuotojai galètų naudoti indeksą, noredami ịvertinti galimą lankytojų skaičių, planuodami kurorto plètros programas (De Freitas ir kt., 2004). Tyrimai naudojant ši indeksą buvo atlikti Europoje, Šiaurès Amerikoje ir Australijoje (De Freitas ir kt., 2008). K. Zaninovicius (2013), remdamasis CIT indekso reikšmèmis, įvertino Adrijos pakrantès turizmo sąlygas. Priimtinos arba idealios sąlygos paplūdimio turizmui vyrauja nuo birželio iki rugsèjo mèn. Adrijos šiaurèje, bet užsitęsia nuo gegužès iki spalio mèn. pietinejje dalyje. Tačiau dviračių turizmui tinkantis laikotarpis trunka ilgiau palei visą Adrijos pakrantę. A. Nemethas (2015) atliko CIT vertinimą Balatono ežero (Vengrija) regionui. Turizmo klimato potencialo pasikeitimai buvo ivvertinti pagal CIT per du standartinius trisdešimties metų laikotarpius: 1961-1990 ir 1981-2010 metais. Nustatyta, kad „idealių“ dienų dažnumas vasaros mènesiais per pastaruosius penkiasdešimt metų padidèjo 5-6 \%, o tuo pat metu „nepriimtinu“ dienu santykis nuo balandžio pabaigos iki rugpjūčio pabaigos vidutiniškai sumažèjo 3-6 \%.

Šio darbo tikslas yra ịvertinti esamas šiltojo sezono (gegužè-rugsèjis) klimatines turizmo sąlygas šalies pajūryje. Lietuvos pajūris buvo analizuotas pagal tris turizmo klimato indeksus: TCI, CIT ir TCIM, pastarasis indeksas pasirinktas remiantis A. Katovcsio ir J. Ungerio (2014) pasiūlyta TCI indekso modifikacija. TCI indeksas apima daug meteorologiniu parametrų, kurie nusako tinkamumo sąlygas vertinamoje teritorijoje. CIT indeksas idomus, nes jis ivertina ne tik meteorologinius parametrus, bet ir žmogaus apsirengimą, aktyvumą. Be to, jis skirtas tik paplūdimiams. Per pastarajji dešimtmeti Lietuvos pajūrio klimatinis turistinis potencialas buvo nagrinètas I. Klybienès (2008), A. Galvonaitès ir kt. (2015), J. Kažio ir I. Malūnavičiūtès (2015), 
S. Dalinkevičiūtès (2017), J. Kažio ir S. Dalinkevičiūtès (2017) darbuose. Svarbu paminèti, kad Lietuvoje atlikta ir paplūdimiuose besilankančių poilsiautojų srautų analizė (Žilinskas ir kt., 2003; Akevičiūtè ir kt. 2004; Eidikonienè, Žilinskas, 2011a; 2011b; Žilinskas, Eidukonienė, 2012).

\section{PRADINIAI DUOMENYS IR DARBO METODIKA}

Tyrimui panaudoti trijų Baltijos jūros pakrantejje esančių Lietuvos meteorologijos stočių (1 pav.) - Palangos, Klaipedos ir Nidos - duomenys. Nors visos stotys patenka ị Lietuvos pajūrio regioną, tačiau jų padètis jūros atžvilgiu yra skirtinga:
- Nidos meteorologijos stotis įsikūrusi ant marių kranto ir nuo jūros yra atitolusi apie $2 \mathrm{~km}$. Aukštis virš jūros lygio $2 \mathrm{~m}$. Ji yra tarsi užuovèjoje nuo jūros pučiančių vakarų vejuu. Todèl išsiruošus i pajūrị reikètų ịvesti tam tikrą atviro pajūrio orų „pataisą“ (Galvonaitè ir kt., 2015).

- Klaipedos meteorologijos stotis įsikūrusi netoli Klaipèdos jūros vartų, tačiau yra apsupta pastatų, todèl nèra tiesioginès prieigos prie Baltijos jūros. Aukštis virš jūros lygio 6,2 m.

- Palangos miestą reprezentuoja Palangos aviacinè meteorologijos stotis, esanti į rytus nuo miesto. Atstumas iki jūros apie $2 \mathrm{~km}$, stotis įsikūrusi atviroje vietoje. Aukštis virš jūros lygio $10 \mathrm{~m}$.

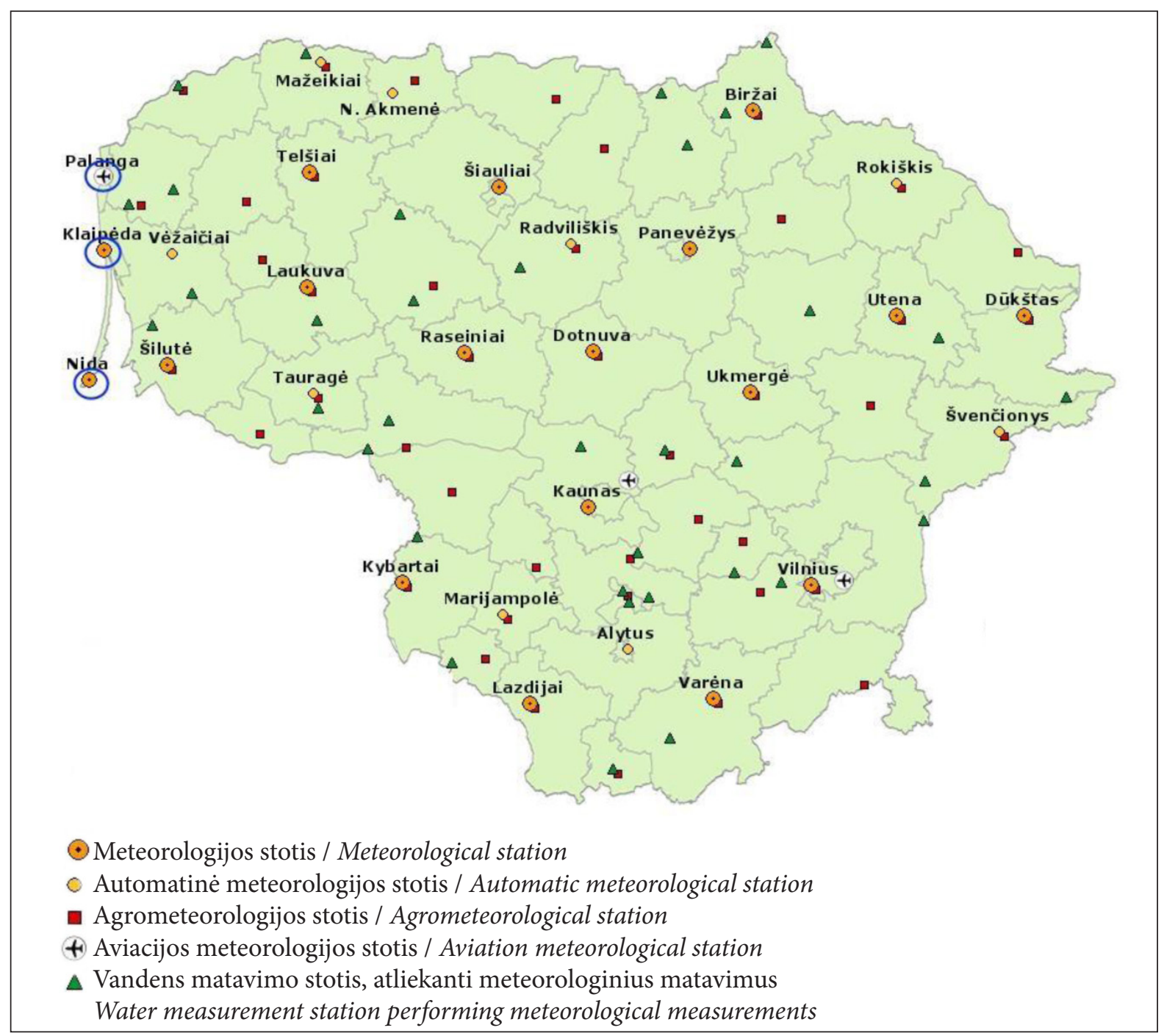

1 pav. Lietuvos hidrometeorologinių stebejjimų tinklo žemèlapis su pažymètomis stotimis (apskritimai), kurių duomenys buvo naudojami tyrimui (Lietuvos hidrometeorologijos tarnyba prie Aplinkos ministerijos, 2018) Fig. 1. Map of the Lithuanian hydrometeorological observation with the marked stations near Baltic Sea (circled) used in this research (modified according to Lithuanian Hydrometeorological Service, 2018) 
Tyrimui buvo panaudoti 23 metų (1993-2016) gegužès-rugsèjo mèn. meteorologiniai duomenys. TCI indeksui buvo naudojama kiekvienos dienos vidutinè paros oro temperatūra $\left({ }^{\circ} \mathrm{C}\right)$, maksimali oro temperatūra $\left({ }^{\circ} \mathrm{C}\right)$, minimalus oro drègnumas $(\%)$, santykinis oro drègnumas (\%), vidutinis vèjo greitis $(\mathrm{km} / \mathrm{h})$, saulès spindejjimo trukmè (val./dieną), kritulių kiekis (mm). CIT indeksui buvo naudojami paros valandiniai duomenys, pasirinkta 15 val. (12 val. pagal UTC), nes maždaug tokiu metu pliaže galima sutikti daugiausia žmonių. Šiam indeksui buvo naudojama oro temperatūra $\left({ }^{\circ} \mathrm{C}\right)$, vejo greitis $(\mathrm{m} / \mathrm{s})$, debesuotumas (oktais), 15 val. kritulių kiekis $(\mathrm{mm})$, santykinè drègmè (\%). Debesuotumas buvo apskaičiuotas kaip 12, 15 ir 18 val. matavimo terminų vidurkis, kad geriau atspindètų dienos debesuotumo ciklą. Kadangi kritulių matavimai atliekami kas 6 val., pasirinktas 15 val. terminas, kuris apima šešių valandų laikotarpi - nuo 9 iki 15 val.

TCI indeksas, kitaip žinomas kaip Mieczkowskio metodas, sukurtas 1985 metais. Jis skirtas integruoti klimato elementus turizmo reikmėms parodant, kad visi klimato kintamieji yra svarbūs turizmui. Taip siekiama vienu indeksu įvertinti bendrąsias turizmo sąlygas, nepriklausomai nuo regiono ar / ir sezono. Šis indeksas susieja dvi bioklimatines kombinacijas ir tris nepriklausomus klimato parametrus. Jis skaičiuojamas pagal formulę (Mieczkowski, 1985):

$$
\mathrm{TCI}=2 \times(4 \mathrm{CID}+\mathrm{CIA}+2 \mathrm{R}+2 \mathrm{~S}+\mathrm{W})
$$

CID - dienos terminio komforto indeksas, apskaičiuojamas naudojant vidutinę aukščiausią oro temperatūrą ir vidutinị minimalų santykinį drègnumą; CIA - paros terminio komforto indeksas, susidedantis iš paros vidutinès oro temperatūros ir paros vidutinio santykinio drègnumo; $\mathrm{R}$ - kritulių kiekis; $S$ - saulès spindejjimo intensyvumas (spindejjimo trukmè); W - vidutinis vejjo greitis. Atitinkamai kiekvienas dèmuo sudaro tam tikrą viso indekso procentinę dalį: CID $40 \%$, CIA $10 \%$, R $20 \%$, S $20 \%$ ir W $10 \%$.

TCI indeksui būtina apskaičiuoti dar du indeksus - CIA ir CID (1 formulè). Kiekvienas parametras yra skirstomas pagal rangą nuo 0 iki 5 naudojant 1 lenteleje pateiktas vidutines mènesio reikšmes. Itvertinus visus trijų miestų rodiklius, skaičiuojamas turistinis klimato indeksas (TCI). Tada paaiškejja, ị kokị intervalą jis patenka (gali būti nuo -30 iki 100) (2 lentelè).

Remiantis Vengrijos kolegu darbais (Kavocs, Unger, 2014), TCI Mieczkowskio indeksas buvo sutrumpintas ir pakeista jo struktūra. Standartinèje formuleje naudojami CID ir CIA indeksai buvo pakeisti ì vieną PET terminị indeksą (3 lentelè). PET indeksas buvo apskaičiuotas pagal santykini drègnumą ir vidutinę paros temperatūrą. Modifikuotas TCIM buvo apskaičiuojamas pagal formulę (Kavocs, Unger, 2014):

$$
\mathrm{TCIM}=2 \times(2 \mathrm{PET}+2 \mathrm{R}+2 \mathrm{~S}+\mathrm{W})
$$

1 lentelè. Mènesio rodiklių reikšmių klasifikacijos lentelè (pagal Mieczkowski, 1985)

\begin{tabular}{|c|c|c|c|c|}
\hline $\begin{array}{c}\text { Rangas } \\
\text { Rank no. }\end{array}$ & $\begin{array}{c}\text { Efektyvioji temperatūra }{ }^{\circ} \mathrm{C} \\
\text { Effective temperature, }{ }^{\circ} \mathrm{C}\end{array}$ & $\begin{array}{c}\text { Kritulių suma } \mathrm{mm} \\
\text { Sum of precipitation, } \mathrm{mm}\end{array}$ & $\begin{array}{c}\text { Saulès spindèjimo } \\
\text { trukmè val./dieną } \\
\text { Sunshine duration, h/day }\end{array}$ & $\begin{array}{l}\text { Vèjo greitis } \mathrm{km} / \mathrm{h} \\
\text { Wind speed, } \mathrm{km} / \mathrm{h}\end{array}$ \\
\hline 3,5 & $17 ; 29$ & $45,0-59,9$ & 7 & $9,04-12,23$ \\
\hline 3,0 & $16 ; 30$ & $60,0-74,9$ & 6 & $12,24-19,79$ \\
\hline 2,5 & $10-15 ; 31$ & $75,0-89,9$ & 5 & $19,80-24,29$ \\
\hline 5,0 & $20-26$ & $0,0-14,9$ & $\geq 10$ & $<2,88$ \\
\hline 4,5 & $19 ; 27$ & $15,0-29,9$ & 9 & $2,88-5,75$ \\
\hline 4,0 & $18 ; 28$ & $30,0-44,9$ & 8 & $5,76-9,03$ \\
\hline 2,0 & $5-9 ; 32$ & $90,0-104,9$ & 4 & $24,30-28,79$ \\
\hline 1,5 & $0-4 ; 33$ & $105,0-119,9$ & 3 & $28,80-38,52$ \\
\hline 1.0 & $-5--1 ; 34$ & $120,0-134,9$ & 2 & \\
\hline 0,5 & 35 & $135,0-149,9$ & 1 & \\
\hline 0,0 & $>36 ;-10--6$ & $>150,0$ & $<1$ & $>38,52$ \\
\hline
\end{tabular}

Table 1. Table of indicator rankings (monthly values) (according to Mieczkowski, 1985) 
2 lentelè. Turistinio klimato indekso vertinimo kategorijos (pagal Mieczkowski, 1985)

Table 2. Categories of Tourism Climate Index ratings (according to Mieczkowski, 1985)

\begin{tabular}{cc}
\hline $\begin{array}{c}\text { TCI intervalai } \\
\text { TCI score }\end{array}$ & $\begin{array}{c}\text { Vertintinos sąlygos } \\
\text { Descriptive category }\end{array}$ \\
\hline $90-100$ & Idealios / Ideal \\
\hline $80-89$ & Puikios / Excellent \\
\hline $70-79$ & Labai geros / Very good \\
\hline $60-69$ & Geros / Good \\
\hline $50-59$ & Priimtinos / Acceptable \\
\hline $40-49$ & Ribinès / Marginal \\
\hline $30-39$ & Nepalankios / Unfavourable \\
\hline $20-29$ & $\begin{array}{c}\text { Labai nepalankios } \\
\text { Very unfavourable }\end{array}$ \\
\hline $10-19$ & $\begin{array}{c}\text { Ekstremaliai nepalankios } \\
\text { Extremely unfavourable }\end{array}$ \\
\hline $9--9$ & Negalimos / Impossible \\
\hline$-10--30$ & Neimanomos / Invidious \\
\hline
\end{tabular}

3 lentelè. PET rodiklio rangai (pagal Kovacs, Unger, 2014)

Table 3. PET indicator ranks (according to Kovacs, Unger, 2014)

PET reikšmès ${ }^{\circ} \mathrm{C} /$ PET values, ${ }^{\circ} \mathrm{C}$ Rangas / Rankno.

\begin{tabular}{cc}
\hline $35,1-41,0$ & 1,9 \\
\hline $29,1-35,0$ & 3,5 \\
\hline $23,1-29,0$ & 4,7 \\
\hline $18,1-23,0$ & 5,0 \\
\hline $13,1-18,0$ & 4,7 \\
\hline $8,1-13,0$ & 3,9 \\
\hline $4,1-8,0$ & 2,8 \\
\hline $0,1-4,0$ & 1,6 \\
\hline$-10,0-0,0$ & 0,3 \\
\hline
\end{tabular}

PET - terminis pojūtis, nusakomas pagal vidutinę oro temperatūrą ir santykinį drègnumą; $\mathrm{R}$ - kritulių kiekis; $\mathrm{S}$ - saulès spindejjimo intensyvumas (spindejimo trukmè); W - vidutinis vejjo greitis.

PET indeksas - vienas iš universalių terminių indeksų, pasiūlyta fiziologiškai ekvivalentinè temperatūra (Höppe, 1999). PET patogus naudoti, nes išreiškiamas visiems îprastais vienetais $-{ }^{\circ} \mathrm{C}$. Universalus indeksas gali būti pritaikytas skaičiuojant bendrus klimatinius rodiklius, nustatant mikroklimatines ypatybes.

CIT indeksas sukurtas $2003 \mathrm{~m}$. (De Freitas ir kt., 2004). Jis yra vienas naujausių indeksų, skirtų klimatinèms turizmo tinkamumo sąlygoms vertinti, be to, reikia paminèti, kad yra skirtas tik paplūdimiams. Šis indeksas naudingas turistams ir turizmo imonèms, planuojantiems atostogas prie jūros. Indeksas išreiškiamas kaip trijų aspektų funkcija (f): terminio (T), fizinio (P) ir estetinio (A), jiems ìvertinti reikalingi meteorologiniai duomenys. Indeksas apibrèžiamas pagal formulę (De Freitas ir kt., 2004):

$$
\mathrm{CIT}=\mathrm{f}[(\mathrm{T}, \mathrm{A}) \times \mathrm{P}] ;
$$

$\mathrm{T}$ - terminis pojūtis, nusakomas ASHRAE skale; A - estetinis patrauklumas, kurị apibūdina debesuotumas; P - fizinès ribos, kurias lemia kritulių kiekis ir vejjo stiprumas.

Terminị pojūtị galima apibrèžti naudojantis terminiais indeksais. Terminiam pojūčiui nusakyti yra nemažai indeksų, tačiau šiame tyrime buvo naudotas PMV (angl. Predicted Mean Vote) (Fanger, 1970). Jam apskaičiuoti buvo naudojama RayMan 1.2 programa. Duomenų vertinimas vykdytas atsižvelgiant ị kriterijų reikšmes (4 lentelè), tada remiantis gautais rezultatais nusakomos klimatinès turizmo sąlygos (5 lentelè).

4 lentelè. CIT vertinimo kriterijai ir reikšmès (pagal De Freitas ir kt., 2008)

Table 4. CIT rating criteria and meanings (according to De Freitas et al., 2008)

\begin{tabular}{|c|c|c|c|c|}
\hline $\begin{array}{l}\text { PMV reikšmės } \\
P M V \text { values }\end{array}$ & $\begin{array}{c}\text { Debesuotumas, } \\
\leq 4 \text { balai } \\
\text { Cloudiness, } \\
\leq 4 \text { points }\end{array}$ & $\begin{array}{l}\text { Debesuotumas, } \\
\geq 5 \text { balai } \\
\text { Cloudiness, } \\
\geq 5 \text { points }\end{array}$ & $\begin{array}{c}\text { Krituliai, } \\
>3 \mathrm{~mm} \\
\text { Precipitation, } \\
>3 \mathrm{~mm}\end{array}$ & $\begin{array}{l}\text { Vèjo greitis, } \\
\geq 6 \mathrm{~m} / \mathrm{s} \\
\text { Wind speed, } \\
\geq 6 \mathrm{~m} / \mathrm{s}\end{array}$ \\
\hline Labai karšta, +4 / Very hot +4 & 4 & 3 & 2 & 2 \\
\hline Karšta, $+3 / H o t+3$ & 6 & 5 & 2 & 2 \\
\hline Šilta, $+2 /$ Warm +2 & 7 & 5 & 2 & 2 \\
\hline
\end{tabular}


4 lentelè. (tęsinys)

Table 4. (continued)

\begin{tabular}{|c|c|c|c|c|}
\hline $\begin{array}{c}\text { PMV reikšmès } \\
\text { PMV values }\end{array}$ & $\begin{array}{c}\text { Debesuotumas, } \\
\leq 4 \text { balai } \\
\text { Cloudiness, } \\
\leq 4 \text { points }\end{array}$ & $\begin{array}{l}\text { Debesuotumas, } \\
\geq 5 \text { balai } \\
\text { Cloudiness, } \\
\geq 5 \text { points }\end{array}$ & $\begin{array}{c}\text { Krituliai, } \\
>3 \mathrm{~mm} \\
\text { Precipitation, } \\
>3 \mathrm{~mm}\end{array}$ & $\begin{array}{l}\text { Vèjo greitis, } \\
\geq 6 \mathrm{~m} / \mathrm{s} \\
\text { Wind speed, } \\
\geq 6 \mathrm{~m} / \mathrm{s}\end{array}$ \\
\hline $\begin{array}{l}\text { Šiek tiek šilta, }+1 \\
\text { Slightly warm }+1\end{array}$ & 6 & 4 & 2 & 2 \\
\hline $\begin{array}{l}\text { Neutralu, } 0 \\
\text { Indifferent } 0\end{array}$ & 5 & 3 & 2 & 2 \\
\hline $\begin{array}{l}\text { Šiek tiek vèsu, }-1 \\
\text { Slightly cool }-1\end{array}$ & 4 & 3 & 2 & 2 \\
\hline $\begin{array}{l}\text { Vèsu, }-2 \\
\text { Cool }-2\end{array}$ & 3 & 2 & 1 & 1 \\
\hline $\begin{array}{l}\text { Šalta, }-3 \\
\text { Cold }-3\end{array}$ & 2 & 1 & 1 & 1 \\
\hline $\begin{array}{c}\text { Labai šalta, }-4 \\
\text { Very cold }-4\end{array}$ & 1 & 1 & 1 & 1 \\
\hline
\end{tabular}

5 lentelè. CIT vertinimo kategorijos (pagal De Freitas ir kt., 2008)

Table 5. CIT rating categories (according to De Freitas et al., 2008)

\begin{tabular}{c|c|c|c|c|c|c}
\hline $\mathbf{1}$ & $\mathbf{2}$ & $\mathbf{3}$ & $\mathbf{4}$ & $\mathbf{5}$ & $\mathbf{6}$ & $\mathbf{7}$ \\
\hline $\begin{array}{c}\text { Labai } \\
\text { netinkamos } \\
\text { Verypoor }\end{array}$ & $\begin{array}{c}\text { Netinkamos } \\
\text { Poor }\end{array}$ & $\begin{array}{c}\text { Pakankamai } \\
\text { netinkamos } \\
\text { Fairly poor }\end{array}$ & $\begin{array}{c}\text { Ribinès } \\
\text { (bet priimtinos) } \\
\text { Marginal } \\
\text { (but acceptable) }\end{array}$ & $\begin{array}{c}\text { Pakankamai } \\
\text { tinkamos } \\
\text { Fairlygood }\end{array}$ & $\begin{array}{c}\text { Tinkamos } \\
\text { Good }\end{array}$ & $\begin{array}{c}\text { Labai } \\
\text { tinkamos } \\
\text { Verygood }\end{array}$ \\
\hline
\end{tabular}

Naudojant meteorologinių rodiklių reikšmes buvo apskaičiuotos kiekvienos dienos TCI, TCIM ir 15 val. CIT indeksų reikšmès Palangos, Klaipedos ir Nidos meteorologijos stotims. Nustatytos vidutinès ir dažniausiai pasitaikančios (moda) atskirų mènesių ir viso šiltojo sezono (gegužè-rugsèjis) indeksų reikšmès. Galiausiai ìvertintas vidutinis viso šiltojo sezono dienų pasikartojimas atskirose indeksų kategorijose (2 ir 5 lentelès) ir išreikštas procentais.

\section{REZULTATAI}

\section{Vidutinės indeksų reikšmės}

Išanalizavus vidutines indeksų reikšmes matyti, kad klimatinès sąlygos skiriasi pagal visus indeksus (2 pav.). Aukščiausios reikšmès gaunamos šilčiausiais mènesiais - liepą ir rugpjūtį. Pagal TCI indeksą gaunamos puikios sąlygos (patenka ì intervalą 80-90), pagal CIT - tik ribinès, bet priimtinos (patenka ił 3-4 reikšmių kategoriją), o pagal modifikuotą TCIM - ribinès arba priimtinos (40-59).

Analizuojant meteorologinius ịvesties duomenis pastebèta, kad būtent liepos ir rugpjūčio mèn. miestams būdinga aukščiausia oro temperatūra ir vyraujantys silpni vejjai, nors fiksuojamas pakankamai didelis konvekcinių kritulių kiekis. Mažiausia turistų Lietuvos pajūrio miestai sulaukia rugsejjo mèn., kai oro temperatūra pradeda kristi, o dèl trumpejančios dienos oras nespeja ǐšilti, be to, pradeda pūsti stipresni vejjai, temperatūra krenta žemyn, palyginti su rugpjūčio ir liepos mènesiais. Rugsèjo mèn. turistiniai klimato indeksai nukrenta viena ar net dviem kategorijomis žemiau, vadinasi, sąlygos tampa labiau nepalankios (2 pav.), nors pagal TCI indeksą sąlygos vis dar išlieka gerų sąlygų kategorijoje. Apibendrinant galima pasakyti, kad per sezoną sąlygos būna nuo puikių iki gerų (pagal TCI), nuo ribinių iki priimtinų (pagal TCIM) ir nuo ribinių, bet priimtinų, iki netinkamų (pagal CIT). 


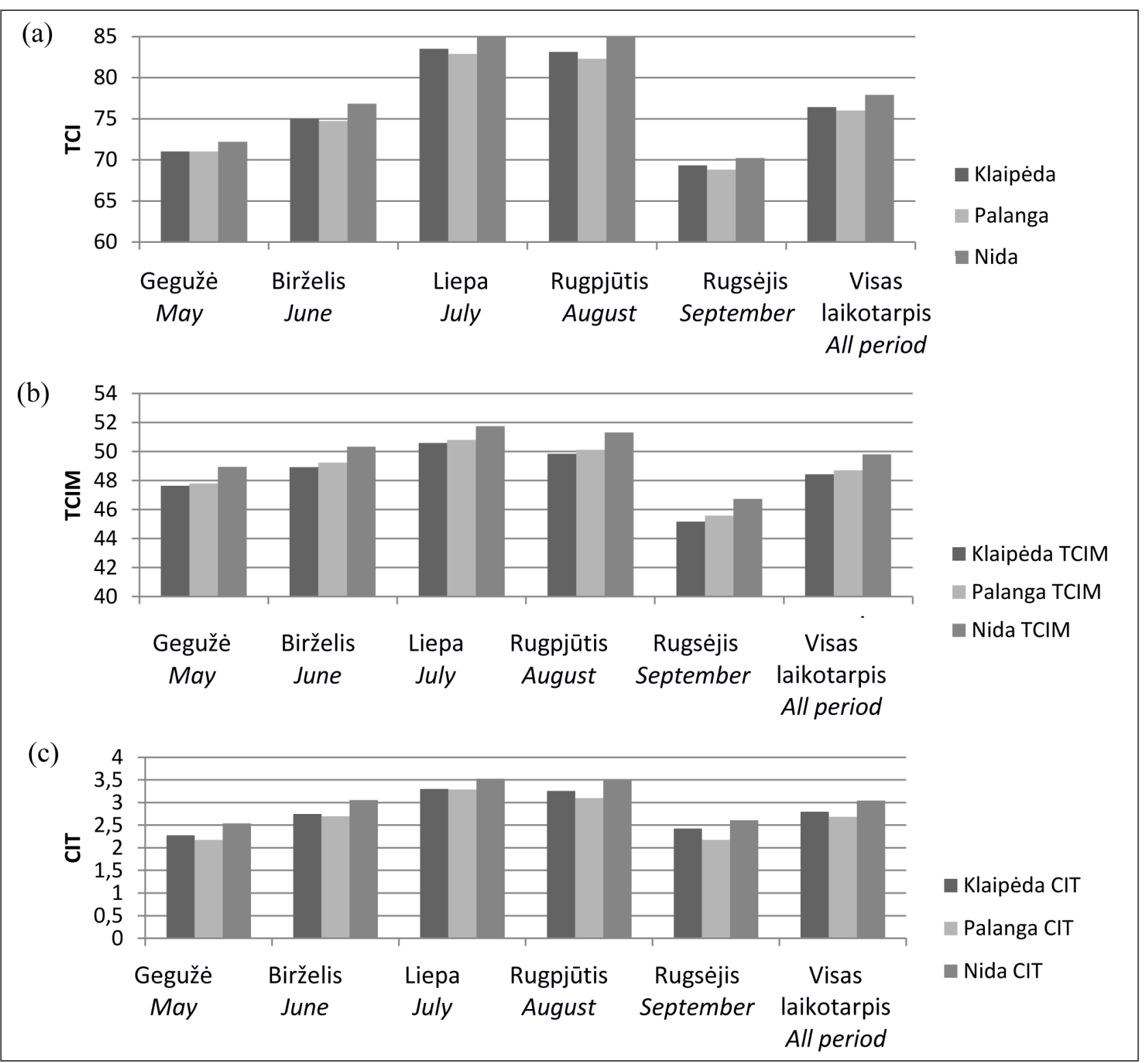

2 pav. TCI (a), TCIM (b) ir CIT (c) vidutinès daugiametès reikšmės kiekvieną mènesị ir per visą šiltąji laikotarpị 1993-2016 m.

Fig. 2. TCI (a), TCIM (b) and CIT (c) average monthly and whole warm season values per 1993-2016

Dažniausiai pasikartojančios indeksų reikšmės

Vertinant ị tam tikrą kategoriją patenkančias reikšmes (3 pav.) pastebèta, kad šilčiausiais mènesiais dažniausiai pasikartojančios visų indeksų reikšmès yra didesnès nei vidutinès. Remiantis TCI indeksu, dažniausiai reikšmès patenka i 90-100 kategoriją visuose miestuose, tad galima daryti išvadą, kad šilčiausiais mènesiais būna idealios sąlygos. Šiais mènesiais Lietuvos pajūrio miestuose vyrauja gana aukšta temperatūra, silpnas vejjas ir didesnis saulès spindejjimo intensyvumas. Tačiau debesuotų dienų taip pat yra, kadangi CIT indekso reikšmių daugiausia patenka i netinkamų ar net labai netinka- mų sąlygų kategoriją. Tik šilčiausiais mėnesiais yra pasiekiama kiek aukštesnè kategorija - pakankamai netinkamos sąlygos, bet ne visuose miestuose. Galima teigti, kad vieninteleje Nidoje yra šiek tiek palankesnis klimatas turizmui.

Atlikus tyrimą taip pat paaiškëjo, kad aukštų TCI reikšmių pasikartojimas per visą tiriamaji laikotarpi tampa vis dažnesnis liepos mènesị. Tai lemia kiekvienais metais vis dažniau fiksuojama labai aukšta oro temperatūra, šiek tiek pasikeitęs kritulių kiekis (mažiau dienų su krituliais), pučiantis nestiprus, šiltas vejjas. Tačiau rugpjūčio mèn. dažniausiai pasikartojančių reikšmių skaičius su aukštomis 


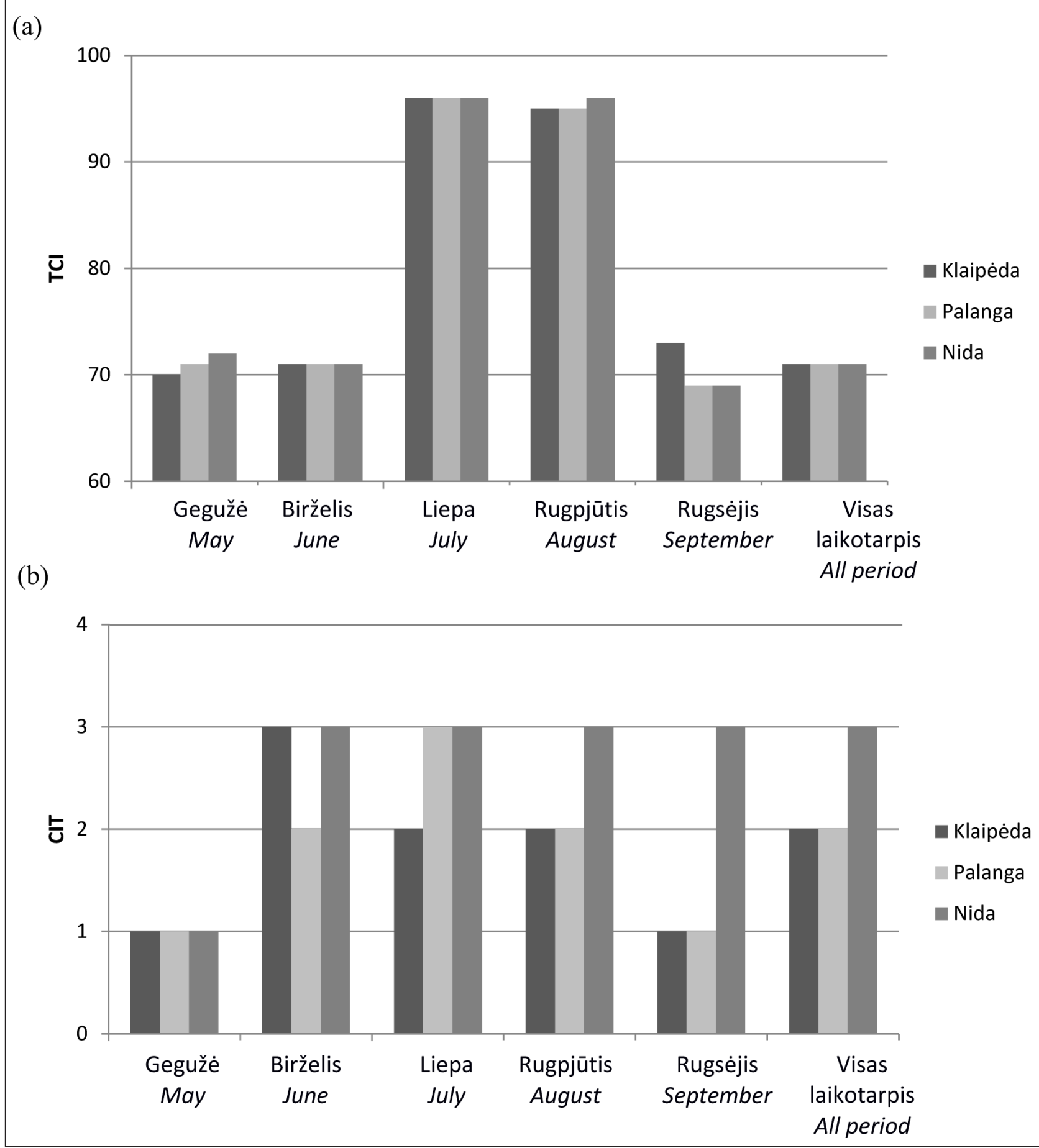

3 pav. TCI (a) ir CIT (b) modos reikšmès kiekvieną mėnesị ir per visą šiltąji laikotarpi 1993-2016 m. Fig. 3. TCI (a) and CIT (b) moda of monthly and whole warm season values per 1993-2016

indeksų reikšmėmis per visą tirtą laikotarpi mažèja, tai reiškia, kad daugiau dienų būna debesuotų, dažnesnès yra vasarinès liūtys, kai iškrenta daug kritulių, taip pat padaugèja vejjuotų dienų.

\section{Dienų pasiskirstymas indeksų kategorijose}

Atliekant tyrimą buvo ịvertinta, kiek procentiškai dienų patenka ì kiekvieną intervalą (6 lentelè).
Nustatyta, kur kokių dienų yra daugiausia, kokių mažiausia. Toks analizès būdas tinkamiausias, kai norima išsiaiškinti, koks miestas buvo geras turizmui. Palankiausias sąlygas turi Nida, būtent ten pagal visus indeksus tokių dienų susidaro daugiausia. Mažiausias potencialas Klaipėdoje ir Palangoje.

Nustatyta, kad panašus dienų pasiskirstymas visuose miestuose, kai TCI patenka ị labai gerų 
6 lentelè. TCI, TCIM ir CIT reikšmių intervalai šiltuoju metų sezonu, patenkančių ị intervalus dienų skaičius, išreikštas procentais

Table 6. Distribution of TCI, TCIM, and CIT value intervals (\%) in diffrent ranking cattegories throughout the warm season

\begin{tabular}{|c|c|c|c|c|c|c|c|}
\hline TCI & $\begin{array}{l}\text { Idealios } \\
\text { Ideal }\end{array}$ & $\begin{array}{c}\text { Puikios } \\
\text { Excellent }\end{array}$ & $\begin{array}{c}\text { Labai geros } \\
\text { Very good }\end{array}$ & $\begin{array}{l}\text { Geros } \\
\text { Good }\end{array}$ & $\begin{array}{l}\text { Priimtinos } \\
\text { Acceptable }\end{array}$ & $\begin{array}{c}\text { Ribinès } \\
\text { Marginal }\end{array}$ & $\begin{array}{l}\text { Nepalankios } \\
\text { Unfavourable }\end{array}$ \\
\hline Klaipèda & 22,1 & 21,1 & 26,3 & 17,3 & 11,4 & 1,8 & 0 \\
\hline Palanga & 20,9 & 20,9 & 27,4 & 17,5 & 11,8 & 1,5 & 0 \\
\hline Nida & 25,8 & 20,3 & 27,8 & 15,0 & 10,1 & 1,0 & 0 \\
\hline TCIM & $\begin{array}{c}\text { Puikios } \\
\text { Excellent }\end{array}$ & $\begin{array}{c}\text { Labai } \\
\text { geros } \\
\text { Very good }\end{array}$ & $\begin{array}{l}\text { Geros } \\
\text { Good }\end{array}$ & $\begin{array}{l}\text { Priimtinos } \\
\text { Acceptable }\end{array}$ & $\begin{array}{l}\text { Ribinès } \\
\text { Marginal }\end{array}$ & $\begin{array}{c}\text { Nepalankios } \\
\text { Unfavourable }\end{array}$ & $\begin{array}{c}\text { Labai } \\
\text { nepalankios } \\
\text { Very } \\
\text { unfavourable }\end{array}$ \\
\hline Klaipėda & 0 & 0 & 0,0 & 54,7 & 27,4 & 16,9 & 1,0 \\
\hline Palanga & 0 & 0 & 0,0 & 58,0 & 25,2 & 16,2 & 0,6 \\
\hline Nida & 0 & 0 & 0,1 & 62,6 & 22,4 & 14,4 & 0,5 \\
\hline CIT & $\begin{array}{c}\text { Labai } \\
\text { tinkamos } \\
\text { Very good }\end{array}$ & $\begin{array}{l}\text { Tinka- } \\
\text { mos } \\
\text { Good }\end{array}$ & $\begin{array}{c}\text { Pakankamai } \\
\text { tinkamos } \\
\text { Faly good }\end{array}$ & $\begin{array}{c}\text { Ribinès } \\
\text { (bet priimtinos) } \\
\text { Marginal } \\
\text { (but acceptable) }\end{array}$ & $\begin{array}{c}\text { Pakankamai } \\
\text { netinkamos } \\
\text { Fairly poor }\end{array}$ & $\begin{array}{c}\text { Netinkamos } \\
\text { Poor }\end{array}$ & $\begin{array}{c}\text { Labai } \\
\text { netinkamos } \\
\text { Very poor }\end{array}$ \\
\hline Klaipèda & 2,2 & 5,9 & 7,7 & 10,1 & 23,9 & 28,2 & 22,0 \\
\hline Palanga & 1,4 & 4,5 & 6,9 & 9,5 & 26,4 & 28,9 & 22,4 \\
\hline Nida & 2,4 & 6,0 & 9,1 & 12,2 & 31,0 & 25,0 & 14,3 \\
\hline
\end{tabular}

(daugiausia dienų patenka i šią kategoriją visu tirtuoju laikotarpiu) ir priimtinų sąlygų intervalus. Tai reiškia, kad panašus dienų skaičius visuose miestuose pasitaiko su labai geromis ir priimtinomis sąlygomis. Remiantis CIT, panašus dienų skaičius būna visur, kai reikšmè lygi 6 , vadinasi, panašus dienų skaičius miestuose pasižymi tinkamomis sąlygomis. Daugiausia dienų pagal CIT patenka i netinkamas arba pakankamai netinkamas sąlygas. TCIM reikšmès panašios kategorijoje 30-39, tai reiškia, kad pagal ši indeksą nepalankių sąlygų visuose miestuose pasitaiko panašiai. Tirtuoju periodu daugiausia dienų patenka ị priimtinų sąlygų kategoriją. Apibendrinant galima teigti, kad tinkamiausias pajūrio miestas turizmui Lietuvoje - Nida, o mažiausia potencialo turi Palanga. Matoma, kad pagal dienų skaičių TCIM priartejo prie CIT reikšmių, nors ir daugiau dienų su geresnèmis sąlygomis rodo TCIM indeksas. Skirtumai galèjo susidaryti dèl nevienodos metodikos, skirtingo meteorologinių parametrų naudojimo ir indeksą stipriau veikiamų įvairių meteorologinių parametrų.

\section{DISKUSIJA}

\section{Turizmo sąlygos Lietuvos pajūryje}

Žmonès dažniausiai praleisti atostogų renkasi jūrą ar didelị vandens telkinị turinčią valstybę. Lietuva taip pat turi nedideli jūros pakrantès ruožą, tačiau jis nèra toks populiarus kaip kitų valstybių, bet turistų iš Vokietijos, Rusijos, Baltarusijos, Ukrainos ar Lenkijos sulaukiame gana dažnai. Patys lietuviai irgi renkasi atostogas mūsų pajūryje. Kaip jau galima suprasti, pajūris yra patraukliausias turizmui, todèl didelis demesys skiriamas jo orams, ypač šiltuoju metu.

Lietuvos pajūris - specifinio klimato Lietuvos dalis. Pajūris - stipresnio vejo, žemesnès temperatūros šiltuoju sezonu, mažesnio debesuotumo, ilgesnès saulès spindejjimo trukmès ir mažesnio kritulių kiekio zona (Bukantis ir kt., 2007; Galvonaitè ir kt., 2015). Iš esmès pagrindiniai Baltijos pajūrio klimatą formuojantys veiksniai yra vyraujanti atlantinio oro cirkuliacija ir tiesiogine Baltijos jūros ịtaka (Griciūtè ir kt., 1979).

Svarbiausi turistiniai ir rekreaciniai veiksniai jūros vanduo, paplūdimiai ir mikroklimatas - yra 
stipriau ar silpniau susiję su gamtiniu pajūrio regiono potencialu, kartu ir su klimatu (Bukantis ir kt., 2007). Pavyzdžiui, Lietuvoje esanti Kuršių nerijos dalis pasižymi ne tik savotiškomis fizinèmis geografinèmis sąlygomis, bet ir klimatinèmis, ypač mikroklimatinėmis, savybėmis, kurias suformuoja betarpiška jūros kaimynyste iš vienos pusès ir Kuršių marių vandenys iš kitos, sudetingas reljefas bei paklotinio paviršiaus ivvairovè (Griciūtè ir kt., 1979).

Lietuvoje nuolat plečiasi ir vystosi rekreacinès teritorijos, populiareja kurortinis gydymas, poilsis ir turizmas, tačiau mikroklimato ypatybès iki šiol mažai ištirtos (Galvonaitè ir kt., 2015). Pajūrio regione plètojamos ìvairios rekreacijos rūšys, tačiau populiariausias išlieka poilsiavimas vasarą (Bukantis ir kt., 2007). Tipinis poilsiautojų srauto dinamikos pasiskirstymas bėgant laikui (per dieną, savaitę ir poilsio sezoną) kinta pasikeitus meteorologinèms sąlygoms. Per poilsio sezoną (gegužę-rugsèjị) rekreantai taip pat atskirais mènesiais pasiskirsto skirtingai. Poilsiauti paplūdimiuose pradedama jau nuo gegužès vidurio (10-25 d.), kai saule, nors ir nelabai kaitri, vis dažniau ima šviesti, oro temperatūra dieną neretai siekia $20{ }^{\circ} \mathrm{C}$ ir daugiau. Tačiau poilsiautojų pagausejja tik nuo birželio 15-20 dienos. Daugiausia poilsiautojų būna vasaros antroje puseje (nuo liepos $15 \mathrm{~d}$. iki rugpjūčio 15-20 d.), kai oro temperatūra svyruoja apie $24-29{ }^{\circ} \mathrm{C}$, o vandens apie $17-22^{\circ} \mathrm{C}$. Tai aukščiausia temperatūra per metus, taip pat ívairiausia renginių ir paslaugu pasiūla. Vèliau poilsiautojų pradeda nuosekliai mažèti, ypač staigiai sumažèja rugsèjo pradžioje (Žilinskas ir kt., 2003; Eidikonienè, Žilinskas, 2011a; Žilinskas, Eidikonienè, 2012).

\section{Indeksų rezultatų interpretacija ir palyginimas}

Visi apskaičiuoti indeksai (TCI, TCIM, CIT) pateikè labai skirtingus rezultatus $(2,3$ pav. ir 6 lentelè). Indeksų skirtumus galima paaiškinti daugeliu aspektų. Visu pirma visuose indeksuose buvo naudojami labai skirtingi meteorologiniai rodikliai (1-3 formulès). Kita priežastis - CIT ir TCIM indeksai j̇vertina žmogaus terminị komfortą (naudojami PMV ir PET jutiminiai indeksai), kas taip pat sumažino indeksų reikšmes. Dar viena priežastis - tai nevienodų parametrų svarbumas indeksams. Debesuotumas yra itin svarbus rodiklis skaičiuojant CIT indeksą, o skirtingi temperatūros rodikliai (PET, CIA, CID) igyja didesnę reikšmę skaičiuojant TCI indeksą (1 formulè). Galiausiai reikia prisiminti indeksų taikomąą paskirtị. TCI orientuotas ị bendras vidutines ménesio klimato sąlygas (Mieczkowski, 1985), o CIT labiau pritaikytas prie žmogaus fiziologinès būsenos ir paremtas poilsiautojų pojūčių interpretacija, jis leidžia nusakyti esamas sąlygas bet kuriuo paros metu (De Freitas ir kt., 2008). Norint CIT pritaikyti kitai veiklai nei poilsiavimui paplūdimyje, reikia keisti įvesties rodiklius. Adrijos jūros pakrantei CIT buvo modifikuotas dviračių turizmui (Zaninovic, 2013). Tyrimu klimatiniai duomenys buvo paimti iš meteorologinių stočių (1 pav.), tai visiškai atitinka TCI vidutinių klimatinių turizmo sąlygų koncepciją, tačiau CIT yra skirtas paplūdimiams ir betarpiškai juose išmatuotiems rodikliams. Apibendrinat galima teigti, kad šiuo metu, remiantis vidutinémis klimatinèmis sąlygomis (Galvonaite ir kt., 2015), TCI (arba TCIM) yra geresnis pasirinkimas vertinant Lietuvos pajūrio miestų turistini potencialą.

Kadangi klimatinès turizmo sąlygos buvo skaičiuojamos ìvairiems metų laikotarpiams, atsiranda galimybè palyginti skirtingų autorių (Klybienè, 2008; Galvonaitè ir kt., 2015; Dalinkevičiūté, 2017) gautas TCI vidutines reikšmes (7 lentelè). Pastebèta, kad sąlygos Lietuvos pajūryje darosi vis palankesnès. Palyginus vidutines 1961-1990 ir 1981-2010 m. TCI reikšmes matyti, kad klimatinès turizmo sąlygos Palangoje ir Nidoje tampa vis optimalesnès (Galvonaitė ir kt., 2015). Šiek tiek teigiamos TCI ir CIT indeksu kaitos tendencijos per 1993-2016 m. Palangoje, Klaipedoje ir Nidoje buvo pateiktos S. Dalinkevičiūtès (2017) tyrime. Panašios tendencijos užfiksuotos ir visame Baltijos jūros baseine apskaičiavus paplūdimio turizmo sąlygų kaitą per 1980-2009 m. naudojant UTCI terminị indeksą (Kažys, Malūnavičiūtè, 2015). Didžiąja dalimi palankios turizmui sąlygos vasaros metu nustatytos Lenkijos mokslininkų (Świątek, 2014, Nidzgorska-Lencewicz, 2015; Kolendowicz ir kt., 2017). UTCI terminis indeksas naudotas Gdanske (Nidzgorska-Lencewicz, 2015) ir pietinès Baltijos jūros dalyje (Kolendowicz ir kt., 2017). Nustatyta, kad vidutiniškai neutralios terminès sąlygos vyrauja nuo gegužès iki rugsėjo. M. Świątek (2014), naudodama 1981-2010 m. Greisvaldo (Greifswald) ir 
7 lentelè. Skirtingų autorių ir laikotarpių vidutinės TCI reikšmès Nidoje ir Palangoje. Pajuodintas šriftas rodo pagerẻjusias sąlygas, palyginti su ankstesniais tyrimų laikotarpiais

Table 7. Average TCI values according to different authors and time periods in Nida and Palanga. Improvement of conditions compared to earlier research periods are bolded

\begin{tabular}{|c|c|c|c|c|}
\hline \multirow{2}{*}{ Mènuo / Month } & \multicolumn{2}{|c|}{ Galvonaitè ir kt., 2015} & \multirow{2}{*}{$\begin{array}{c}\text { Klybienè, } 2008 \\
1993-2006\end{array}$} & \multirow{2}{*}{$\begin{array}{c}\text { Dalinkevičiūtė, } 2017 \\
1993-2016\end{array}$} \\
\hline & $1961-1990$ & 1981-2010 & & \\
\hline & \multicolumn{4}{|c|}{ Neringa (Nida) } \\
\hline Gegužè / May & $60-69$ & $60-69$ & $70-79$ & $70-79$ \\
\hline Birželis / June & $70-79$ & $70-79$ & $70-79$ & $70-79$ \\
\hline Liepa / July & $80-89$ & $80-89$ & $80-89$ & $80-89$ \\
\hline Rugpjūtis / August & $80-89$ & $80-89$ & $80-89$ & $80-89$ \\
\hline \multirow[t]{2}{*}{ Rugsèjis / September } & $50-59$ & $50-59$ & $60-69$ & 70-79 \\
\hline & \multicolumn{4}{|c|}{ Palanga } \\
\hline Gegužè / May & $60-69$ & $60-69$ & $60-69$ & 70-79 \\
\hline Birželis / June & $70-79$ & $70-79$ & $70-79$ & $70-79$ \\
\hline Liepa / July & $80-89$ & $80-89$ & $80-89$ & $80-89$ \\
\hline Rugpjūtis / August & $70-79$ & $80-89$ & $80-89$ & $80-89$ \\
\hline Rugsèjis / September & $50-59$ & $50-59$ & $60-69$ & $60-69$ \\
\hline
\end{tabular}

Svinousce (Świnoujście) bei 1985-2010 m. Helo (Hel) ir Gdynès (Gdynia) skirtingus meteorologinius ir biometeorologinius rodiklius nustatè, kad palankiausias metas neaktyviam paplūdimių turizmui yra liepos mèn. ir primoji rugpjūčio pusè.

Ateities klimato pokyčiai turès tiek teigiamų, tiek neigimų pasekmių turizmui Baltijos jūros regione (Kūle ir kt., 2013). A. Moreno ir B. Amelungas (2009), modeliuodami BCI (Beach Climate Index) reikšmių pokyčius Europoje 2060 m., nustatė, kad didžiojoje Baltijos jūros baseino dalyje sąlygos nepakis arba šiek tiek pagerès. Vertinant turizmo sąlygų pokyčius, remiantis TCI indeksu, nustatyta, kad 2071-2100 m. geresnès sąlygos turizmui vasaromis ísivyraus šiurinèje Europos dalyje (Perch-Nielsen, 2010), o globaliai oro temperatūrai išaugus $2{ }^{\circ} \mathrm{C}$ Baltijos regione TCI reikšmès pakils 2-5 vienetais (Grillakis ir kt., 2016).

Klimato kaita Lietuvos pajūrio regione sukels naujų išbandymų visai turizmo sistemai, tačiau kartu suteiks naujų galimybių ateityje išnaudoti rekreacinius resursus naujomis aplinkos sąlygomis (Bukantis ir kt., 2007). Dèl augančios vidutinès oro temperatūros ir mažai besikeičiančio kritulių kiekio per XXI a. gegužès-rugsèjo mèn. (Keršytè ir kt., 2015), tiketina, kad vis daugiau dienų bus idealios arba puikios sąlygos, o dienų, kai bus nepriimtinos sąlygos, gerokai sumažès. Dèl klimato kaitos poveikio galimai visų indeksų reikšmès sieks potencialiai tinkamų sąlygu ribas. Tačiau klimato kaita sukelia ir kitų padarinių - dažniau sulauksime stiprių liūčių (Rimkus ir kt., 2009), besikaitaliojančių su sausringais laikotarpiais (Rimkus ir kt., 2012). Tai gegužès-rugsẻjo mèn. lems didesnę paplūdimio turizmo sąlygų ìvairovę. J. Kažys ir S. Dalinkevičiūtè (2017) nustatė, kad vertinat dabartines klimatiniu indeksų pastovumo ir tinkamumo sąlygas tik apie 30 \% TCI ir 5-10 \% CIT reikšmių atitinka šiuos „orų gerumo“ paplūdimių turizmui kriterijus Lietuvos pajūryje. Tikètina, kad ateityje esant didelei oro kaitai tokie indeksai kaip CIT ir TCIM, turintys žmogaus šiluminio pojūčio ir santykio su aplinka vertinimo rodiklių, ìgys pranašumą prieš elementarius meteorologiniais rodikliais paremtus indeksus.

\section{IŠVADOS}

1. Visi trys klimatiniai turizmo indeksai (TCI, TCIM, CIT) parodè, kad vidutiniškai tinkamiausios sąlygos paplūdimių turizmui Lietuvos 
Baltijos jūros krante susidaro liepos-rugpjūčio mèn., o mažiausia palankios - rugsèjo mènesị. Apskaičiuotų per 1993-2016 m. vidutinių TCI reikšmių pasiskirstymas gegužès-rugsèjo mèn. sutampa su ankstesnių tyrimų rezultatais.

2. Nors visi trys indeksai (TCI, TCIM, CIT), skirti klimatiniam turizmo potencialui vertinti, ir šiltojo metų sezono rezultatai itin skiriasi. Akivaizdu, kad TCIM indekse oro temperatūrą pakeitus žmogaus jutimine temperatūra (išreikšta PET indeksu) vidutinès pastarojo indekso reikšmès tampa ribines (40-49), ima tolti nuo TCI labai gery (70-79) ir artèti prie pakankamai netinkamu CIT reikšmių (2-3).

3. Dažniausiai pasitaikančios TCI indekso sąlygos yra idealios (TCI > 90) liepos-rugpjūčio mèn., o likusiais mènesiais svyruoja tarp geru ir labai geru $(60<\mathrm{TCI}<80)$, CIT indekso reikšmès gegužès, rugsèjo mèn. svyruoja tarp labai netinkamu $(\mathrm{CIT}=1)$ ir pakankamai netinkamu $(\mathrm{CIT}=3)$ vasaros metu. Viena pagrindinių TCI ir CIT skirtumų priežasčiu yra ta, kad pastarojo indekso skaičiavimuose naudojama ne paros oro temperatūros, o konkrečios valandos žmogaus jutiminès temperatūros reikšmè (išreikšta PMV indeksu).

4. Remiantis TCI indeksu, gegužès-rugsèjo mèn. daugiau nei du trečdaliai dienų patenka ị labai geru ar aukštesnị intervalą (TCI > 70), analogiškas procentas CIT reikšmių patenka ị pakankamai netinkamu ar blogesnių sąlygų intervalą (CIT < 4), o pagal TCIM indeksą - daugiau nei $50 \%$ dienų užfiksuotos priimtinos $(50<$ TCIM < 60) sąlygos paplūdimių turizmui Baltijos jūros pakrantèje.

5. Lyginant trijų Lietuvos pajūrio zonoje esančių meteorologijos stočių duomenis matyti, kad pagal TCI, TCIM ir CIT indeksų reikšmes geriausios klimatinès turizmo sąlygos susidaro Nidoje, prasčiausios - Klaipèdoje (pagal TCI ir TCIM) ir Palangoje (pagal CIT). Nidai būdinga aukštesnè oro temperatūra ir silpnesnis vejas, palyginti su kitais dviem miestais.

Gauta 20180419

Priimta 20180528

\section{LITERATŪRA}

1. Akevičiūtė J., Žilinskas G., Jarmalavičius D. 2004. Poilsiautojų srauto sklaida Kuršių nerijos pliažuose. Geografijos metraštis. 37(1-2): 162-174.
2. Amiranashvili A., Matzarakis A., Kartvelishvili L. 2008. Tourism climateindexin Tibilisi. Transactions of the Georgian Institute of Hydrometeorology. 115: 2-3.

3. Bukantis A., Dailidènienė I., Česniulevičius A., Gelumbauksiate Ž., Jarmalavičius D., Kavolyte R., Kažys J., Liukaitytė J., Morkūnaitė R., Pilkaitytė R., Paškauskas R., Povilinskienè R., Razinkovas A., Rimkus E., Stankūnavičius G., Stonevičius E., Šečkus J., Taločkaitė E., Žilinskas G. 2007. Klimato kaita: prisitaikymas ir jos poveikis Lietuvos pajūryje. Vilnius: Vilniaus universiteto leidykla. 108 p.

4. Dalinkevičiūte S. 2017. Turizmo klimato indeksu TCI ir CIT taikymas Lietuvos pajūryje: bakalauro darbas. Vilnius: Vilniaus universitetas.

5. De Freitas C. R., Matzarakis A. 2005. Recent developments in tourism climatology. German Meteorological Society. 1: 1-6.

6. De Freitas C. R., Scott D., McBoyle G. 2004. A new generation climate index for tourism and recreation. Advances in Tourism Climatology. International Workshop on Climate, Tourism and Recreation, 19-26.

7. De Freitas C. R., Scott D., McBoyle G. 2008. A second generation climate index for tourism (CIT): specification and verification. International Journal of Biometeorology. 52(5): 399-407.

8. Eidikonienè J., Žilinskas G. 2011a. Poilsiautoju srauto sklaida Klaipèdos rekreacinèje zonoje. Geografija. 47(1): 30-37.

9. Eidikonienè J., Žilinskas G. 2011b. Poilsiautojų srauto sklaida Šventosios rekreacineje zonoje. Geografija. 47(2): 117-124.

10. Fanger P. O. 1970. Thermal Comfort-Analysis and Applications in Environmental Engineering. Copenhagen: Danish Technical Press.

11. Galvonaite A., Kilpys J., Kitrienė Z., Valiukas D. 2015. Lietuvos kurortu klimatas. Vilnius: Lietuvos hidrometeorologijos tarnyba prie Aplinkos ministerijos. $104 \mathrm{p}$.

12. Griciūtè A., Kavaliauskas B., Tomkus J. 1979. Lietuvos antropoklimatas. Vilnius: Mokslas. $137 \mathrm{p}$.

13. Grillakis M. G., Koutroulis A. G., Seiradakis K. D., Tsanis I. K. 2016. Implications of $2{ }^{\circ} \mathrm{C}$ global warming in European summer tourism. Climate Services. 1:30-38.

14. Hoogendoorn G., Fitchett J. M. 2018. Tourism and climate change: a review of adaptation for Africa. Current Issues in Tourism. 21(7): 742-759.

15. Höppe P. 1999. The physiological equivalent temperature - a universal index for the biometeorological assessment of the thermal environment. International Journal of Biometeorology. 43: 71-75. 
16. Katovcs A., Unger J. 2014 Modification of the Tourism Climatic Index to Central European climatic conditions - examples. Quarterly Journal of the Hungarian Meteorological Service. 118(2): 152-161.

17. Kažys J., Dalinkevičiūtė S. 2017. Climatology of tourism indices TCI and CIT at Lithuanian seaside. Extended Abstracts of the 21st International Congress of Biometeorology (ICB2017). Durham: Durham University, 6A.3: 61-65.

18. Kažys J., Malūnavičiūtė I. 2015. The evaluation of summer beaching conditions on the Baltic Sea coasts using the UTCI index. International Journal of Climate Change: Impacts and Responses. 7(4): 41-59.

19. Klybienè I. 2008. Rytinio Baltijos jūros regiono turistinio klimatinio potencialo vertinimas: bakalauro darbas. Vilnius: Vilniaus universitetas.

20. Kolendowicz L., Półrolniczak M., Szyga-Pluta K., Bednorz E. 2017. Human-biometeorological conditions in the southern Baltic coast based on the universal thermal climate index (UTCI). Theoretical and Applied Climatology.

21. Kūle L., Haller I., Varjopuro R., Alberth J. 2013. Climate Change Impacts on Coastal Tourism in the Baltic Sea Region. Baltadapt Report \# 6. Danish Meteorological Institute, Copenhagen.

22. Rimkus E., Kažys J., Bukantis A. 2009. Gausių kritulių Lietuvoje prognozė XXI amžiuje pagal regioninį CCLM modeli. Geografija. 45(2): 122-130.

23. Rimkus E., Valiukas D., Kažys J., Gečaitė I., Stonevičius E. 2012. Dryness dynamics of the Baltic Sea region. Baltica. 25(2): 129-142.

24. Tang M. 2013. Camparing the Tourism Climate Index and Holiday Climate Index in Major European Urban Destinations. $\mathrm{PhD}$ thesis, University of Waterloo, Canada, 139 p.
25. Mieczkowski Z. 1985. The Tourism Climatic Index: a method of evaluating world climates for tourism. The Canadian Geographer. 29: 220-233.

26. Moreno A., Amelung B. 2009. Climate change and tourist comfort on Europe's beaches in summer: A reassessment. Coastal Management. 37(6): 550568.

27. Nemeth A. 2015. Observed changes in the tourism climate potential of the lake Balaton region based on the second generation climate index for tourism (CIT). Proceedings of the 4th International Conference on Climate, Tourism and Recreation, 78-81.

28. Nidzgorska-Lencewicz J. 2015. Variability of human-biometeorological conditions in Gdańsk. Polish Journal of Environmental Studies. 24: 215226.

29. Perch-Nielsen S. L. 2010. The vulnerability of beach tourism to climate change-an index approach. Climatic Change. 100(3): 579-606.

30. Perry A. 2011. More heat and drought - can mediterranean tourism survive and prosper? Report of a Workshop Held at Porto Carras, Neos Marmaras, Halkidiki, Greece: 40.

31. Swiątek M. (2014. Seasonal variability of climatic conditions for tourism and recreation along the southern coast of the Baltic Sea. Bulletin of Geography: Physical Geography Series. 7: 57-80.

32. Zaninovic K. 2013. Potential of beach tourism in Croatia using climate index for tourism. EMS Annual Meeting Abstracts. 10: EMS2013-435.

33. Žilinskas G., Akevičiūtè J. Jarmalavičius D. 2003. Poilsiautojų srauto ypatybès Kuršių nerijos jūriniame krante. Geografijos metraštis. 36(2): 174-181.

34. Žilinskas G., Eidikonienè J. 2012. Poilsiautoju srauto sklaida Palangos rekreacinèje zonoje. Geografija. 48(1): 117-124. 
Simona Dalinkevičiūtė, Justas Kažys

\section{CLIMATIC CONDITIONS FOR BEACH TOURISM ON COASTAL AREAS IN LITHUANIA}

\section{Sum mary}

Tourism is one of the most rapid development sectors in the world. For summer tourism, climatic conditions are of higher importance while picking the destination and choosing the right time. Many climatic tourism indices exist in the world. This study focused on TCI (Tourism Climate Index, equation 1), TCIM (a modified version of TCI according to Kavocs \& Unger (2014), equation 2) and a new generation index CIT (Climate Index for Tourism, equation 3) developed by De Freitas et al. (2004). The data from three meteorological stations (Palanga, Klaipeda and Nida) situated on the Baltic coast of Lithuania were used (Fig. 1). The study period covered 24 years (from 1993 to 2016) during the warm season (May-September).

TCI (Table 1) and CIT (Table 4) calculations were based on different meteorological parameters. Additionally, PET (Physiological Equivalent Temperature) index was calculated for TCIM (Table 3). PMV (Predicted Mean Vote) index (Table 4), the main parameter for CIT estimations was calculated using RayMan 1.2 software. The values of indices were distributed between different TCI (Table 2) and CIT (Table 5) suitability categories for beaching tourism.

Firstly, the daily values of TCI, TCIM and CIT were transformed to monthly and whole period (May-September) averages in Palanga, Klaipéda and Nida. Secondly, the most repeated values (modes) were found for each month and the entire warm season. Finally, distribution values (in percentage) between different index categories (Tables 2 and 5) were calculated for the May-September period.

According to TCI, TCIM and CIT indices, in Lithuania, the best average conditions for beach tourism exist from July to August, the most unfavourable month is September (Fig. 2). The distribution of average TCI values thought May-September corresponds to the results presented by other authors. Although all three indices (TCI, TCIM, CIT) are applicable for the evaluation of climatic conditions for tourism, the presented results are very different. It is obvious that if air temperature is replaced with apparent temperature (PET index), the average TCIM values (marginal conditions, Fig. 2b) would become more distant from TCI (very good, Fig. 2a) and closer to CIT (fairly poor, Fig. 2c) conditions.

Usually, the mode values of TCI are ideal (TCI > 90) during July-August and range between good and very good $(60<\mathrm{TCI}<80)$ for the rest of the months (Fig. 3a). Meanwhile, the mode values of CIT change from very poor $(\mathrm{CIT}=1)$ to fairly poor $(\mathrm{CIT}=3)$ in May and September (Fig. 3b). One of the main reasons for such huge differences between TCI and CIT is that the hourly measured human apparent temperature (PMV index) was used for CIT calculations instead of daily air temperature values for TCI.

Throughout May-September, more than 2/3 of TCI values fall into the range of very good or higher conditions (TCI > 70); the same amount of CIT values is attributed to fairly poor and lower conditions $(\mathrm{CIT}<4)$ (Table 6). Meanwhile, more than 50 percent of conditions are classified as acceptable $(50<$ TCIM < 60) for TCIM (Table 6).

According to TCI, TCIM and CIT indices, the best climatic conditions for tourism are in Nida, the worst conditions appear in Klaipeda (according to TCI and TSIM) and Palanga (according to CIT). Higher air temperatures and weaker winds are in Nida compared to other two cities' conditions.

A comparison of the distribution of average TCI values in May-September between different authors and time periods revealed that conditions are becoming more suitable for beach tourism in Lithuania (Table 7). However, climate change will bring new challenges in the 21st century, including higher diversity of the values of indices throughout the warm period. It means that such indexes as CIT and TCIM are more demanding for climatic tourism evaluations.

Keywords: tourism, climate, climatic tourism indices, Lithuanian seaside 